\title{
QUALITY OF SOIL AND WATER IN DELTAIC DEPOSITS OF LOUROS AND ARACHTHOS RIVERS RELATED TO KARSTIC ROCKS OF THE WIDER AREA
}

\author{
Papadopoulou K. ${ }^{1}$, and Vriniotis D. ${ }^{2}$ \\ ${ }^{I}$ National and Kapodistrian University of Athens, Faculty of Geology and Geoenvironment, \\ Department of Geography \& Climatology, Panepistimioupoli, Zografou 15784, Athens, Greece \\ ${ }^{2}$ Institute of Geological and Mineralogical Research, Athens
}

\begin{abstract}
The present study focuses on the connection between the existing karstic formations and the quality of soil and water in the River Delta area. The hydrological basins of Louros and Arachthos Rivers (NW Greece) are partially developed on karstic rocks. So the soil is enriched with $\mathrm{CaCO}_{3}$ and there is a natural supply of $\mathrm{Ca}^{++}$, which originates mainly from the limestone and secondarily from gypsum formations. The value of the Cation Exchange Capacity (CEC) of soil is high and in the exchange sites $\mathrm{Ca}^{++}$ions dominate and $\mathrm{Mg}^{++}$secondarily.

Delta water of phreatic and confined aquifer contain high $\mathrm{Ca}^{++}$ion concentrations. The fluctuation of $\mathrm{HCO}_{3}$ values in confined aquifer water is within normal levels. Ions of $\mathrm{SO}_{4}^{--}$that occur in water are derived from the karstic process of gypsum and anhydrite formations. The values of $\mathrm{Na}^{+}$and $\mathrm{Cl}$ content in water are higher in the phreatic aquifer than in ground water. The water in the area of the River Delta is classified as Carbonic water, despite its proximity to the sea.

Therefore, the quality of soil and water of the River Delta area is highly related to the karstic process of carbonate formations, mainly of calcareous and secondarily evaporate sediments.
\end{abstract}

Key words: Deltaic deposits, karstic rocks, water, soil, quality.

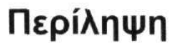

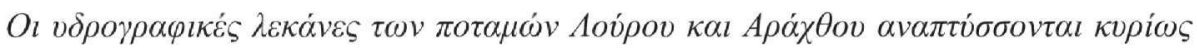

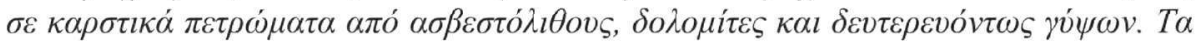

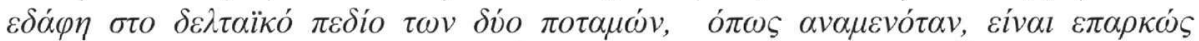

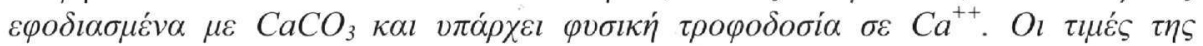

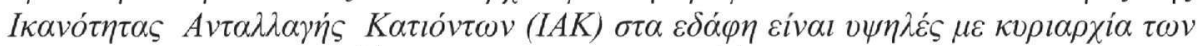

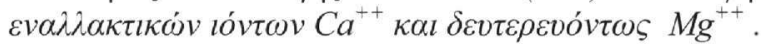

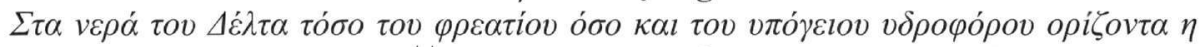

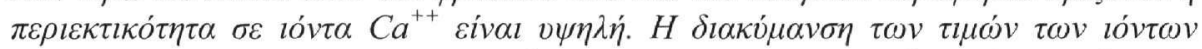

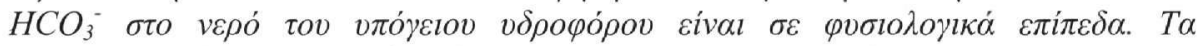

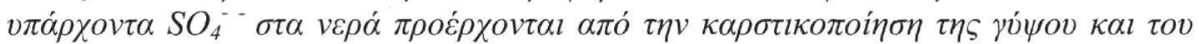

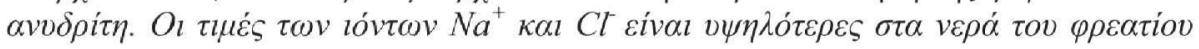




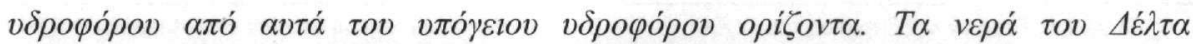

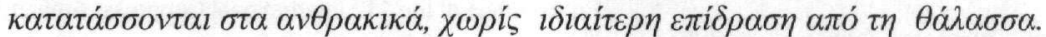

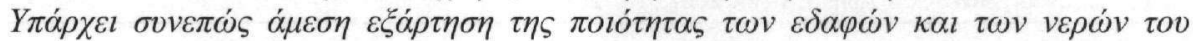

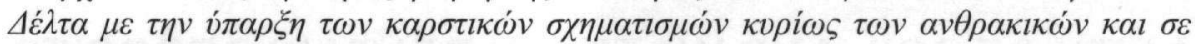

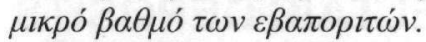

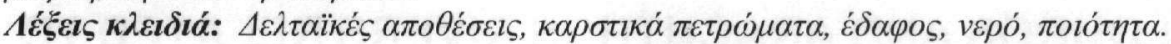

\section{Introduction}

The present study focuses on the quality of soil and water associated with the delta deposits of Louros and Arachthos Rivers and its relation to the presence of karst bedrock within the hydrological basins of the aforementioned rivers.

For this purpose, the $\mathrm{CaCO}_{3}$ content in the soil of the river delta is examined. In addition, the $\mathrm{Ca}^{++}$, $\mathrm{HCO}_{3}{ }^{-}, \mathrm{SO}_{4}{ }^{--}, \mathrm{Mg}^{++}, \mathrm{Na}^{+}$and $\mathrm{Cl}$ content in the phreatic and confined aquifer water of the River Delta area are also studied. The research was carried out under the $2^{\text {nd }}$ Community Support Framework program were used (Vriniotis 2001).

Delta deposits of the Louros and Arachthos Rivers occur between the towns of Arta and Preveza, especially between the river beds of Louros on the west and Arachthos on the east. This plain covers an area of about $330 \mathrm{~km}^{2}$, the highest altitude of which is $22 \mathrm{~m}$. The plain is separated by the Valaora hill $(246 \mathrm{~m})$ on the east and by the Mavrovouni hill $(+292 \mathrm{~m})$ on the west.

The climate of the greater area is mild and changes to continental towards the highlands in the east. The lowest annual precipitation is less than $1,200 \mathrm{~mm}$ at the west coast of the Ionian Sea. Towards the delta area the precipitation is up to $1,600 \mathrm{~mm}$, while towards the north-east, in the mountainous area reaches $2,600 \mathrm{~mm}$ (Boltsis 1986). The annual maximum and minimum temperature, as measured at the Aktio and Arta Meteorological Stations, is $37{ }^{\circ} \mathrm{C}$ and $41{ }^{\circ} \mathrm{C}$, respectively, during the summer period, and $-3.6{ }^{\circ} \mathrm{C}$ and $-7.2{ }^{\circ} \mathrm{C}$ during the winter. In the area under study, the evaporation and humidity are high throughout the year. Precipitation, in combination with the recorded fluctuation in temperature, constitute the main factors that determine the physical - chemical process on the "rock - water - soil - flora - fauna" system.

\section{Geological Setting}

The geological formations that provide material to the alluvial deposits of the Louros-Arachthos River delta belong mainly to the Adriatic-Ionian Unit and secondarily part to the Pindos and Gavrovo-Tripoli Units (Map No 1). The hydrological basin of the Louros River is entirely developed on the geological formations of the Adriatic-Ionian Unit, while that of Arachthos River is extended and on formations of the Pindos and Gavrovo-Tripoli Units. Therefore, there is a differentiation on the composition of the weathered soil materials carried by the two rivers.

The geological formations of the Adriatic-Ionian Unit that are encountered within the hydrological basins of the rivers are as follows:

- Gypsum formations, which are mainly found within breccia of calcareous origin.

- Limestone formations of "Sinion" and "Pantokratora" of Upper Triassic-Liassic age. During the Jurassic period, the geotectonic zone was submerged and subdivided into three elongated parts, the axial, western and eastern sections. Schist and siliceous formations prevail in the axial area, while limestone is dominant at the edges. Later than Malmian, the "Vigla" limestone was deposited, while breccia with calcareous constituents was deposited till the Eocene period. Later on, flysch was deposited till Lower Miocene, whilst sandstone and marl were deposited during the Aquitanian-Burdigalian. 


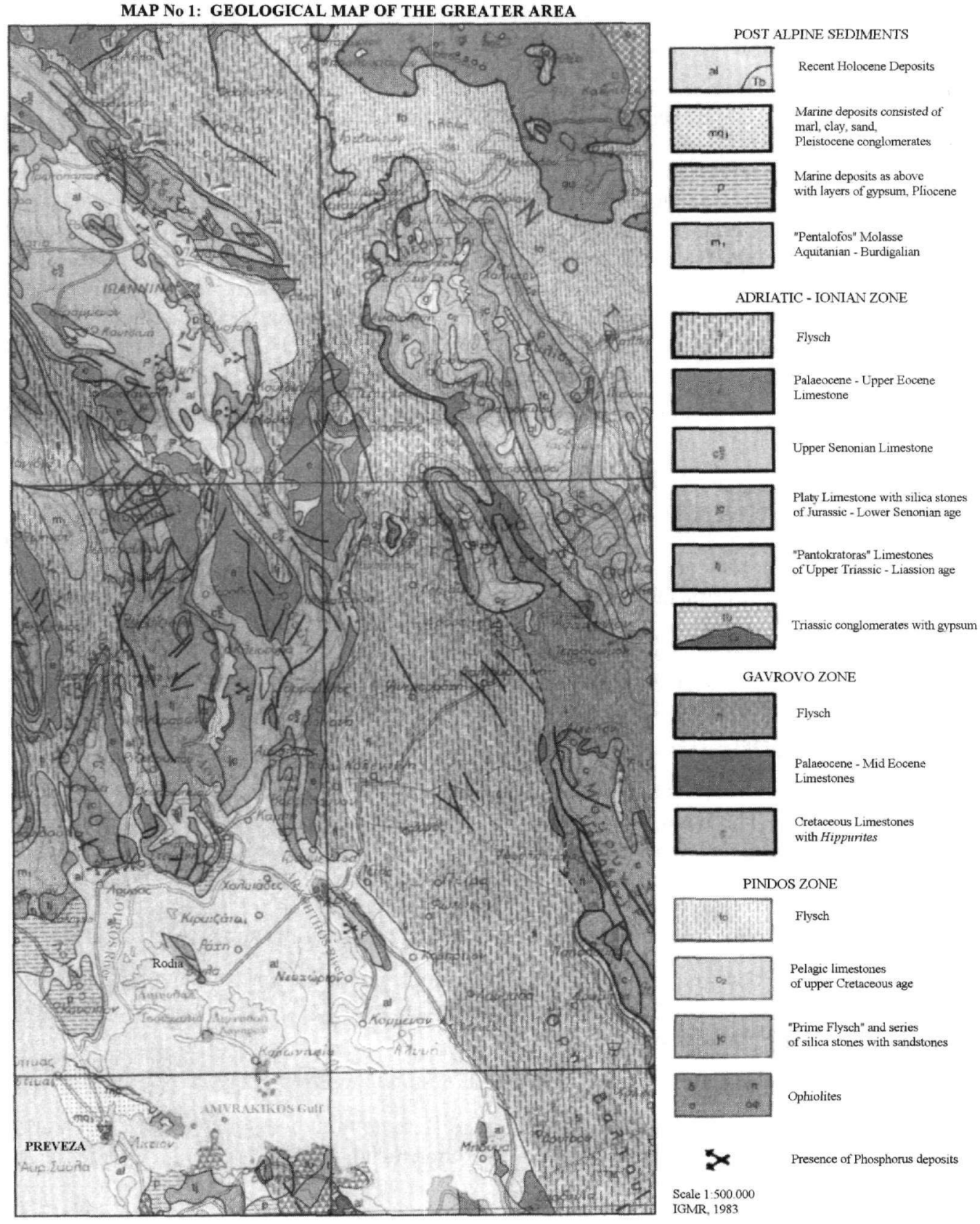

The geological formations of the Gavrovo-Tripoli Unit are found on many locations within the hydrological basin of Arachthos River, towards E and NE. The alpine sediments are composed of upper Triassic dolomite, followed by Jurassic limestone, melanic Cretaceous limestone, and by cordonance limestone of Eocene epoch. The Eocene-Oligocene flysch covers the limestone series.

The geological formations of the Pindos Unit, with the overlying trusted ophiolites, supply with material the Arachthos River, especially the northern part of its tributaries. Dolomite and limestone of mid-Triassic age are the older formations of this Unit. The platy limestone and siliceous formations alternating with schist, and the schist-keratolithic complex formation of Lower Cretaceous age follow. The upward succession continues with marl, sandstone and breccia 
of Lower Cretaceous age and limestone of the Upper Cretaceous period are found. The aforementioned series of the Mesozoic period end with flysch until the beginning of Lower Oligocene age.

With respect to the post-alpine sediments, the following occur in the area:

- The "Pentalofos" molasse of Aquitanian-Burdigalian age.

- Neogene formations of Pliocene epoch, such as terrestrial conglomerate, clayey sand, white marl and marine clay with layers of gypsum. Gypsum formations are observed close to Palaeorofos village, as well as west of the Nea Filippiada settlement, north of the Amvrakikos Gulf. They are mainly found within a conglomerate zone, the direction of which is NNW-SSE. This formation is present between the Ziros Lake and the area located $4 \mathrm{~km}$ approximately north of the Nea Kerasounta settlement. These conglomerates are part of the Pleistocene sediments of Archagellos and Nea Filippiada settlements.

- Quaternary deposits are mainly found on the plain of the River Delta area. Their composition depends on the type of geological formations that supply with matErial the rivers, the distance of transfer, the water flow of rivers and other relevant factors.

- With respect to tectonism, the overthrust of the Units from east towards the west and the development of synclinal folds, alternating with anticlinal folds of NNW-SSE direction characterize the study area (Aubouin, 1959). Faults mainly follow the NNW-SSE direction, while there are several faults - usually more recent - that follow the E-W direction. The faults are created by the "tectonism of breaks" that followed the "tectonism of thrusting up thrusting". Basic element of the tectonism, acting on the greater area, is the presence of gypsum, which constituted the sliding plane and developed phenomena of diapirism.

\section{Geomorphology}

The hydrological basin of Arachthos River is developed NNE of the area under study and covers an area of $1,850 \mathrm{~km}^{2}$. The main river bed of Arachthos River is $105 \mathrm{~km}$ long. The hydrological basin of Louros River is developed north of the area under study and covers an area of $685 \mathrm{~km}^{2}$. The length of the main Louros river bed is $73 \mathrm{~km}$. The main river beds of Arachthos and Louros Rivers follow a NNW - SSE direction, similar to the direction of the fold axes of the geological formations prevailing in the greater area and of the Hellenic geotectonic zones (Mertzanis 1992).

The hydrological basin of Arachthos River is made up of geological formations prone to erosion (flysch, marl, sandstone), which produce sediments, as well as karst formations (limestone), constituting $18.5 \%$ of surface exposures.

The hydrological basin of Louros River is made of limestone (approximately $70 \%$ ).

Therefore, there exists a quantitative and qualitative differentiation of sediments carried by the two rivers. The percentage of alluvium supplied by the Arachthos River is greater than the one supplied by Louros River. The Arachthos River delta is adequately developed. Arachthos River has greatly contributed to the development of the plain of Arta (Hellenic Marine Research Centre 1989).

The Arachthos River provides coarse grain material, mainly quartz, and also large quantities of fine-grained silt. They originate from the flysch and the ultramafic geological formations occurring in the upstream hydrological basin of Arachthos River.

The Louros River supplies small quantities of fine-grained materials, as well as angular or rounded gravel of calcareous origin.

The calcareous deposits of Louros River found in the western part of the study area consist of clayey silt. On the contrary, the deposits of Arachthos River found in the eastern-central part are mostly made of sandy silts (Vriniotis 2001). 


\section{Methodology}

\subsection{Geochemistry of Soil}

Soil sampling has been carried out on cultivated land that covers an area of $330 \mathrm{~km}^{2}$. Eighty-seven soil samples were collected from the river delta area. The sample density was one soil sample per $4 \mathrm{~km}^{2}$. Sampling locations were pre-determined. Two samples of 1.5-2.0 kg weight approximately were collected from each sampling location. The soil samples were collected down to a depth of $30 \mathrm{~cm}$. Samples were left to dry and then sieved through the $<10 \mathrm{mesh}$. Several analyses were performed on these soil samples, including the determination of $\mathrm{CaCO}_{3}$ by the Bernard calciummeter and Cation Exchange Capacity (CEC) by atomic absorption.

The results of the analyses were statistically processed by use of ARC - INFO and SURFER software packages. In detail, several statistical parameters were calculated, histograms plotted, and grain-size analysis was carried out.

\subsection{Geochemistry of Water}

Seventy-four water samples were collected, forty-five from the confined aquifer of the area, and twenty-nine from the phreatic.

The confined aquifer water samples were collected from operating boreholes between 35 and $75 \mathrm{~m}$ depth and are distributed evenly over the delta area as far as possible close to the soil sampling locations.

Water samples from the phreatic aquifer were collected from shallow water wells, most of which were not in use. The sampling depth was approximately $9 \mathrm{~m}$ below surface.

The volume of each water sample was $1,000 \mathrm{~cm}^{3}$, and the analyses performed included $\mathrm{Ca}^{++}$, $\mathrm{HCO}_{3}^{-}, \mathrm{SO}_{4}^{--}, \mathrm{Mg}^{++}, \mathrm{Cl}^{-}$and $\mathrm{Na}^{+}$. The ions of $\mathrm{Ca}^{++}, \mathrm{Mg}^{++}, \mathrm{HCO}_{3}^{-}$and $\mathrm{Cl}^{-}$were determined volumetrically by titration, $\mathrm{SO}_{4}^{--}$ion by the spectrometer Hach 4000 , and $\mathrm{Na}^{+}$by atomic absorption PE 2100.

\section{Presentation and Interpretation of Results}

\subsection{Soil}

\subsection{1. $\mathrm{CaCO}_{3}$ Content in Soil}

The statistical distribution of $\mathrm{CaCO}_{3}$ in the delta soil can be seen in the histogram and bar graph of Figure 1, where it is obvious that $54 \%$ of the collected soil samples contain more than $5 \%$ of $\mathrm{CaCO}_{3}$, whereas $40 \%$ of the soil samples contain between $20-26 \%$ of $\mathrm{CaCO}_{3}$.

Therefore, most the river delta soil is adequately supplied by $\mathrm{CaCO}_{3}$. The amount of $\mathrm{CaCO}_{3}$ in soil originates from the limestone formations that constitute the hydrological basin both of Arachthos and Louros Rivers, mainly the one of Louros River.

The presence of $\mathrm{CaCO}_{3}$ is very important due to its hydrolysis by the chemical reaction $\mathrm{CaCO}_{3}+\mathrm{H}_{2} \mathrm{O}+\mathrm{CO}_{2} \Leftrightarrow \mathrm{Ca}\left(\mathrm{HCO}_{3}\right)_{2}$, where $\mathrm{Ca}^{++}, \mathrm{HCO}_{3}{ }^{-}$and $\mathrm{OH}^{-}$ions are released. So, soil existing in the area of the river delta is adequately supplied by components that are essential for soil improvement.

\subsubsection{Cation Exchange Capacity (CEC)}

The nutritive ingredients of soil that are essential for plant growth are held in an exchangeable form. The exchangeable cations affect the texture, infiltration and saturation capacity of soil. The average value of CEC of a productive soil is approximately $15-26 \mathrm{meq}$ per $100 \mathrm{~g}$ of soil. Surplus exchangeable calcium affects positively the aforementioned soil parameters. 
In the area under study, the CEC of all samples is $>12.4 \mathrm{meq} / 100 \mathrm{~g}$ of soil, with an average of 30.8 meq/100 $\mathrm{g}$ of soil (Fig. 1). These high values are mainly attributed to the type of clay minerals and organic matter content. In the exchange sites $\mathrm{Ca}^{2+}$ ions dominate and secondarily $\mathrm{Mg}^{2+}$, resulting in the development of favorable conditions for soil. The source of this $\mathrm{Ca}^{++}$content in soil is primarily the limestone formations and to a minor degree the gypsum formations.

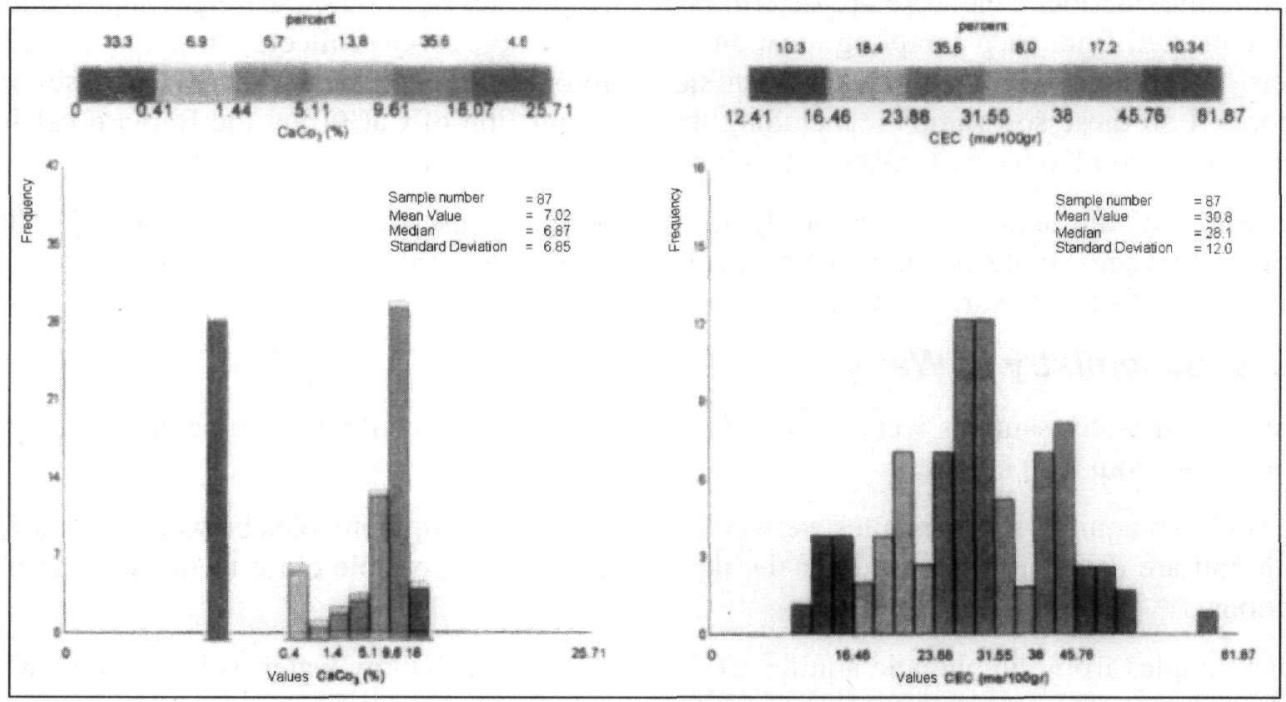

Figure 1 - Charts of $\mathrm{CaCO}_{3}$ and $\mathrm{CEC}$ content in soil (Vriniotis 2001, Map 15 \&17)

\subsection{Water}

\subsection{1. $\mathrm{Ca}^{++}$Cation Content in Water}

Most of the $\mathrm{Ca}^{++}$cations are derived primarily from the hydrolysis of $\mathrm{CaCO}_{3}$ and partially from gypsum formations. As it has already been mentioned, the bedrock and the soil in the study area are rich in $\mathrm{CaCO}_{3}$. Moreover, there are in the area occurrences and deposits of gypsum.

The $\mathrm{Ca}^{++}$content in the water of the phreatic aquifer is up to $13.44 \mathrm{meq} / \mathrm{l}(268 \mathrm{mg} / \mathrm{l})$, with an average value of $5.41 \mathrm{meq} / \mathrm{l}$, whilst in the water of the confined aquifer is up to $6 \mathrm{meq} / \mathrm{l}(120 \mathrm{mg} / \mathrm{l})$, with an average of $4.18 \mathrm{meq} / \mathrm{l}$ (Map No 2). So, water drawn from boreholes is suitable for drinking purposes, whereas that of water from wells is classified as good to moderate, based on the Waterlot diagram.

The increase $\mathrm{CO}_{2}$ content in the phreatic aquifer, which originates from organic matter or from precipitation, leads to a higher $\mathrm{Ca}^{++}$content in the phreatic aquifer water compared to the confined aquifered water. Moreover, in areas supplied by alluvium from Louros River, close to calcareous formations, the $\mathrm{Ca}^{++}$content is high in phreatic aquifer too.

\subsubsection{Bicarbonate $\left(\mathrm{HCO}_{3}{ }^{-}\right)$Content in Water}

The bicarbonate ions are mainly derived from the hydrolysis of $\mathrm{CaCO}_{3}$ in the Delta area. The bicarbonate content in the water of the confined aquifer reaches a maximum value of $8.07 \mathrm{meq} / 1$ (496 mg/l), with an average of $4.54 \mathrm{meq} / \mathrm{l}$. This variation is considered to be within the normal range (Table 1). The $\mathrm{HCO}_{3}{ }^{-}$content of the water in the phreatic aquifer reaches up to $23.44 \mathrm{meq} / \mathrm{l}$ $(1,453 \mathrm{mg} / \mathrm{l})$, with an average of $6.70 \mathrm{meq} / \mathrm{l}$. The values above $9 \mathrm{meq} / \mathrm{l}$ are to be considered anomalous. This is attributed to the decomposition of organic matter in soil, which increase the $\mathrm{CO}_{2}$ content. 


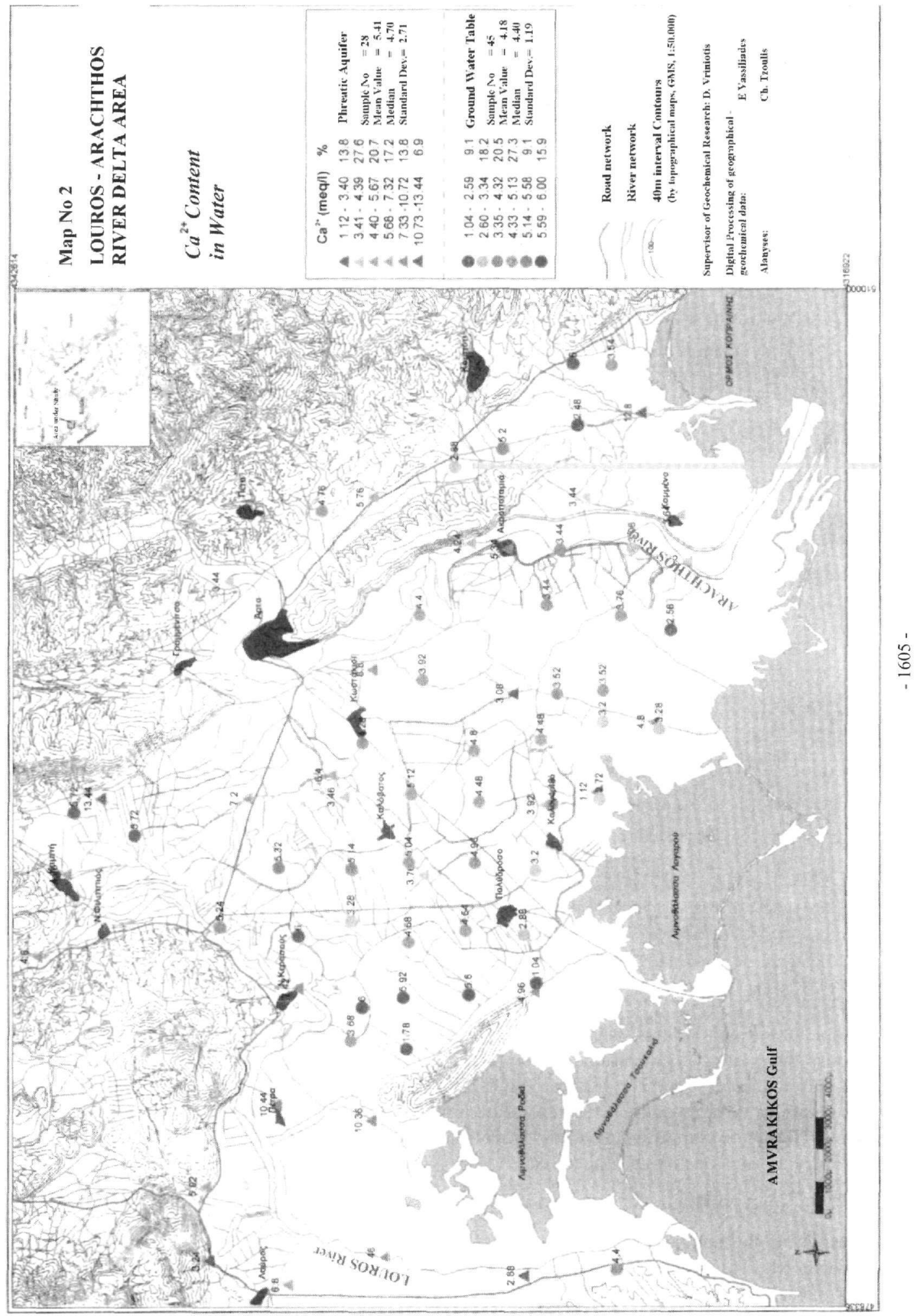


Table 1 - Consistency (\%) of elements in Water (Vriniotis 2001)

\begin{tabular}{|c|c|c|c|c|c|c|c|c|c|}
\hline & $\mathrm{HCO}_{3}(\mathrm{meq} / \mathrm{l})$ & $\%$ & & & & $\mathrm{Mg}^{2+}(\mathrm{meq} / \mathrm{l})$ & $\%$ & \multirow{3}{*}{\multicolumn{2}{|c|}{$\begin{array}{l}\text { Phreatic Aquifer } \\
\text { number of samples }=28\end{array}$}} \\
\hline 1 & $2.64-3.19$ & 13.8 & \multicolumn{2}{|l|}{ Phreatic Aquifer } & 1 & $0.08-1.52$ & 21.4 & & \\
\hline 2 & $3.20-4.21$ & 31.0 & number of samples & $=28$ & 2 & $1.53-2.07$ & 17.9 & & \\
\hline 3 & $4.22-7.34$ & 17.2 & Mean & $=6.70$ & 3 & $2.08-3.75$ & 21.4 & Mean & $=3.40$ \\
\hline 4 & $7.35-9.69$ & 17.2 & Background & $=5.38$ & 4 & $3.76-6.77$ & 21.4 & Background & $=2.50$ \\
\hline 5 & $9.70-16.90$ & 17.2 & Standard deviation & $=4.45$ & 5 & $6.78-9.09$ & 14.3 & Standard deviation $=$ & $=2.65$ \\
\hline 6 & $16.91-23.44$ & 3.4 & & & 6 & $9.10-9.12$ & 3.6 & & \\
\hline 1 & $2.58-3.27$ & 13.6 & \multicolumn{2}{|c|}{ Ground Water Table } & 1 & $0.40-1.32$ & 9.1 & \multicolumn{2}{|c|}{ Ground Water Table } \\
\hline 2 & $3.28-3.91$ & 37.5 & \multicolumn{2}{|c|}{ number of samples $=45$} & 2 & $1.33-1.68$ & 18.2 & \multicolumn{2}{|c|}{ number of samples $=45$} \\
\hline 3 & $3.92-4.68$ & 48.4 & Mean & $=4.54$ & 3 & $1.69-2.14$ & 25.0 & Mean & $=2.38$ \\
\hline 4 & $4.69-5.27$ & 20.5 & Background & $=4.27$ & 4 & $2.15-3.09$ & 20.5 & Background & $=2.00$ \\
\hline 5 & $5.28-6.30$ & 13.6 & \multirow{2}{*}{\multicolumn{2}{|c|}{ Standard deviation $=1.14$}} & 5 & $3.10-3.94$ & 15.9 & \multirow{2}{*}{\multicolumn{2}{|c|}{ Standard deviation $=1.06$}} \\
\hline 6 & $6.31-8.07$ & 6.8 & & & 6 & $3.95-5.40$ & 11.4 & & \\
\hline & $\mathrm{Cl}^{-}(\mathrm{meq} / \mathrm{l})$ & $\%$ & & & & $\mathrm{Na}^{+}(\mathrm{meq} / \mathrm{l})$ & $\%$ & & \\
\hline 1 & $0.35-0.56$ & 18.5 & \multirow{2}{*}{\multicolumn{2}{|c|}{$\begin{array}{l}\text { Phreatic Aquifer } \\
\text { number of samples }=28\end{array}$}} & 1 & $0.26-0.47$ & 11.5 & \multirow{2}{*}{\multicolumn{2}{|c|}{$\begin{array}{l}\text { Phreatic Aquifer } \\
\text { number of samples }=28\end{array}$}} \\
\hline 2 & $0.57-1.20$ & 14.8 & & & 2 & $0.48-1.38$ & 11.5 & & \\
\hline 3 & $1.21-3.71$ & 37.0 & Mean & $=3.90$ & 3 & $1.39-4.04$ & 50.0 & Mean & $=4.22$ \\
\hline 4 & $3.72-7.89$ & 14.8 & Background = & $=2.00$ & 4 & $4.05-8.23$ & 23.1 & Background & $=2.61$ \\
\hline 5 & $7.90-16.76$ & 11.1 & \multirow{2}{*}{\multicolumn{2}{|c|}{ Standard deviation $=4.75$}} & 5 & $8.24-16.78$ & 7.4 & \multirow{2}{*}{\multicolumn{2}{|c|}{ Standard deviation $=6.35$}} \\
\hline 6 & $16.77-17.80$ & 3.7 & & & 6 & $16.79-34.20$ & 3.6 & & \\
\hline 1 & $0.20-0.40$ & 5.4 & \multicolumn{2}{|c|}{ Ground Water Table } & 1 & $0.22-0.52$ & 12.2 & \multicolumn{2}{|c|}{ Ground Water Table } \\
\hline 2 & $0.41-0.48$ & 18.9 & \multicolumn{2}{|c|}{ number of samples $=45$} & 2 & $0.53-0.62$ & 12.2 & \multicolumn{2}{|c|}{ number of samples $=45$} \\
\hline 3 & $0.49-0.85$ & 59.5 & Mean & $=1.08$ & 3 & $0.63-0.90$ & 43.9 & Mean & $=1.29$ \\
\hline 4 & $0.86-2.62$ & 16.2 & Background & $=0.50$ & 4 & $0.91-1.85$ & 14.6 & Background & $=0.70$ \\
\hline 5 & $2.63-5.54$ & 5.1 & \multirow{2}{*}{\multicolumn{2}{|c|}{ Standard deviation $=1.44$}} & 5 & $1.86-3.83$ & 7.3 & \multirow{2}{*}{\multicolumn{2}{|c|}{ Standard deviation $=1.54$}} \\
\hline 6 & $5.55-6.80$ & 4.9 & & & 6 & $3.84-7.52$ & 9.8 & & \\
\hline
\end{tabular}

\subsubsection{Sulphate Ion (SO4־) Content in Water}

The sulphate ion content has values up to $350 \mathrm{mg} / \mathrm{l}$, with an average of $2 \mathrm{meq} / \mathrm{l}(100 \mathrm{mg} / \mathrm{l})$. There were only three sampling locations of the phreatic aquifer where the sulphate ion level in water was greater than $250 \mathrm{mg} / \mathrm{l}$. The highest values were measured in water collected from the area NE of Rodia and Loutrotopos, as well as from the area of the Kerasounta settlement. This constituent originates from the karstified gypsum formations $\left(\mathrm{CaSO}_{4} \cdot 2 \mathrm{H}_{2} \mathrm{O}\right)$ and anhydrite $\left(\mathrm{CaSO}_{4}\right)$ of the Neogene evaporites occurring in the area.

\subsection{4. $\mathrm{Mg}^{++}, \mathrm{Na}^{+}$and $\mathrm{Cl}^{-}$Content in Water}

The results of the analyses are presented in Table 1 . Mainly the $\mathrm{Na}^{+}$and $\mathrm{Cl}^{-}$ion contents and secondarily $\mathrm{Mg}^{2+}$ are higher in the phreatic aquifer water in comparison to that of confined aquifer. This is partially attributed to the transportation of $\mathrm{Na}^{+} \mathrm{Mg}^{2+}$ and $\mathrm{Cl}^{-}$ions by sea spray with the 
airmasses. So karst water of the confined aquifer is not affected by the sea and is of better quality, compared to that of the phreatic aquifer.

In general, water can be classified into the following two types:

i. Water containing carbon

$$
\begin{aligned}
& \mathrm{HCO}_{3}>\mathrm{SO}_{4}^{--}>\mathrm{Cl}^{-} \\
& \mathrm{Ca}^{++}>\mathrm{Mg}^{++}>\mathrm{Na}^{+}
\end{aligned}
$$

ii. Water containing chlorides

$$
\begin{aligned}
& \mathrm{Cl}^{-}>\mathrm{SO}_{4}^{--}>\mathrm{HCO}_{3}{ }^{-} \\
& \mathrm{Na}^{+}>\mathrm{Mg}^{++}>\mathrm{Ca}^{++}
\end{aligned}
$$

According to the above water types (i) and (ii), the geochemical category in which a sample of water can be classified, depends upon the decreasing content of ions and cations, especially on the type of the dominant ion (Kallergis 1968).

Based on the aforementioned results, although the delta water is near the sea, it mainly belongs to the class of Carbonate water. Therefore, water quality is strongly associated with the karstic process of the calcareous formations, prevailing in the study area.

\section{Conclusions}

Based on the above results, the following are concluded:

- Soil in the area of Louros and Arachthos River Delta is sufficiently supplied with $\mathrm{CaCO}_{3}$. This constituent originates from the calcareous formations occurring in the greater area of the hydrological basins, mainly of that of Louros.

- Soil in the area of Louros and Arachthos River Delta is naturally supplied with $\mathrm{Ca}^{++}$, which originates from the existing karstified geological formations, mainly from the limestone and secondarily from gypsum.

- The value of the Cation Exchange Capacity of soil is rather high, and is dominated by the high values of exchangeable $\mathrm{Ca}^{++}$ions.

- In the delta water, both in the phreatic and confined aquifer, a high $\mathrm{Ca}^{++}$ion content is observed. The $\mathrm{Ca}^{++}$ion content is higher in the water of the phreatic aquifer of the area, especially in the adjacent calcareous formations, where alluvial materials are deposited by Louros River.

- The variation of $\mathrm{HCO}_{3}{ }^{-}$content in water of the confined aquifer is within normal levels. In general, the $\mathrm{HCO}_{3}{ }^{-}$ions are mainly formed by the hydrolysis of $\mathrm{CaCO}_{3}$, which occurs in large amounts due to the presence of calcareous formations. The values of the two higher classes in the water of the phreatic aquifer are rather high, which is attributed to the decomposition of organic matter in soil.

- The $\mathrm{SO}_{4}^{--}$ion content in the delta water is derived from the karstified formations of Neogene evaporites occurring in the greater area.

- The values of $\mathrm{Na}^{+}$and $\mathrm{Cl}^{-}$content in water are higher in the phreatic aquifer, whereas the confined aquifer water is not affected by the sea and is of better quality.

- The delta water should be classified as Carbonate water and the potability of borehole water (confined aquifer), with respect to the $\mathrm{Ca}^{++}, \mathrm{Mg}^{++}, \mathrm{Na}^{+}, \mathrm{Cl}^{-}, \mathrm{SO}_{4}^{--}$and $\mathrm{HCO}_{3}{ }^{-}$ion content is good whilst that of the phreatic aquifer is classified as good to moderate.

- It is concluded that there is a close association between the quality of soil and water in the deltaic deposits of Louros and Arachthos Rivers with the occurrence of carbonate formations. 


\section{References}

Aubouin, J., 1959. Contribution a l' etude geologique de la Grece septentrionale: Les confines de 1' Epire et de la Thessalie, Ann. Geol. D. Pays Hell., X, 1-525.

Boltsis, Th., 1986. Contribution to the study of the water balance of the precipitation in the area of Hepirus. PhD Study, Univ. of Athens, Athens.

Bornovas, G., 1960. Observatipns nouvelles sur la geologie des zones preapulienne et ionienne (Grece occidentale), B. S. G. F. (7) II, Paris, 410-414.

Bousquet, B., 1976. La Grece occidentale. Intrerpretation geomorphologique de l' Epire, de 1' Acarnanie et des isles ioniennes, These, Univ. de Paris IV.

Hellenic Marine Research Centre, 1989. Oceanographic study on the Amvrakikos Gulf. Athens, 2.1, 121pp.

I.G.M.E., 1983. Geological Map of Greece, Scale 1:500.000, I.G.M.E., Athens.

Kallergis, G., 1986. Applied hydrogeology, vol. 1. Technical chamber of Greece. Athens

Maratos, G., 1972. Geology of Greece, Ed. GE. MEL. ER., Athens.

Mertzanis, A., 1992. Geomorphological evolution of Amvrakikos Gulf, PhD Study, Geological Dept, Univ. of Athens, Athens, 170 pp. \& Annexes.

Papadopoulou, K., 2002. Lost rivers associated with hazard pollution in Greece, $6^{\text {th }}$ Int. Symposium on History of Speleology and Karstology in ALCADI, Italy, 6pp.

Vriniotis, D., 2001. Soil geochemical survey of deltaic sediments of Louros-Arachthos in combination with hydrogeochemical data, I.G.M.E. Open File Report, Athens, 86 pp. 